\title{
Reduced environmental impact of antibacterial agents applied in fish farms using the LiftUp feed collector system or a hydroacoustic feed detector
}

\author{
A. $\operatorname{Ervik}^{1}$, O. B. Samuelsen ${ }^{2, *}$, J. E. Juell ${ }^{1}$, H. Sveier ${ }^{3}$ \\ ${ }^{1}$ Institute of Marine Research, Strandgaten 229, N-5024 Bergen, Norway \\ ${ }^{2}$ Dept of Clinical Biology, Division of Pharmacology, University of Bergen, Armauer Hansens Hus, N-5021 Bergen, Norway \\ ${ }^{3}$ Felleskjopet, Havbruk, N-4335 Dirdal, Norway
}

\begin{abstract}
High-performance liquid chromatography was used to quantify residues of oxolinic acid and flumequine in muscle of wild fish caught in the vicinity of fish farms using the LiftUp feed collector system or a hydroacoustic feed detector during medication. Both systems are designed to minimise feed waste and thereby the amount of medicated feed entering the surroundings. The result indicates that both systems decrease the supply of medicated pellets to the wild fish during medication, since the mean and maximum concentrations of drugs in muscle of wild fish were reduced compared to fish farms not using this equipment. Therefore, the equipment will reduce the environmental impact of antibacterial agents used in fish farming.
\end{abstract}

KEY WORDS: Aquaculture A Antibacterial agents - Environment

\section{INTRODUCTION}

Previous research has shown that during medication in fish farms, drugs reach the wild fauna (Møster 1986, Björklund et al. 1990, 1991, Samuelsen et al. 1992, Ervik et al. 1994). Possible sources are excess food pellets due to overfeeding, small drug-containing feed particles and drug-containing faeces due to incomplete absorption of the drugs in the fish intestine (Cravedi et al. 1987, Gröndel et al. 1987, Hustvedt et al. 1991). Since observations using underwater cameras indicate that wild fish usually do not eat faeces (J. E. Fosseidengen pers. comm.), excess pellets are thought to be the most important source. In order to reduce drug residues in wild fish during medication, pellets available to the wild fish must be minimised. The Liftup feed collector system and the hydroacoustic feed detector are both designed to minimise feed waste in fish farming (Birkeland \& Johnsen 1991, Juell et al. 1993). In this investigation we examined the spread of drugs to wild fish captured in the vicinity of fish farms using either the LiftUp feed collector or the hydroacoustic feed detector during medication.

\footnotetext{
- Addressee for correspondence
}

\section{MATERIALS AND METHODS}

Chemicals. Oxolinic acid (OXA) and flumequine (FLU) were obtained from Norsk Medisinaldepot A/S (Bergen, Norway). Methanol, acetonitrile, tetrahydrofuran (HPLC-grade), dichloromethane, sodium hydroxide and oxalic acid dihydrate (pa-grade) were all from Merck (Darmstadt, Germany).

Sampling sites. Muscle samples of wild fish were collected at 3 marine fish farms located on the west coast of Norway in the Hordaland region during 1992. A feed detector was installed at Farm 1 while the LiftUp system was used in Farms 2 and 3. At Farm 1, 4000 fish with an average weight of $250 \mathrm{~g}$ were treated with $160 \mathrm{~kg}$ Aqualets containing a total of $5 \mathrm{~kg}$ FLU. The medication took place from 2 to 11 October 1992. The seawater temperature was $14^{\circ} \mathrm{C}$ on average. At Farm 2, 5880 fish with an average weight of $1.1 \mathrm{~kg}$ were given $210 \mathrm{~kg}$ pelleted dry feed $(7 \mathrm{~mm})$ containing a total of $3.3 \mathrm{~kg}$ of OXA. The medication took place from 21 to 30 June 1992. The seawater temperature was $16^{\circ} \mathrm{C}$ on average. At Farm 3,370 fish with an average weight of $4.1 \mathrm{~kg}$ were given $35 \mathrm{~kg}$ pelleted dry feed $(9 \mathrm{~mm})$ containing a total of $1.75 \mathrm{~kg}$ of OXA. The medication took place from 9 to 18 August 1992. The seawater temperature was $12.5^{\circ} \mathrm{C}$ on average. 


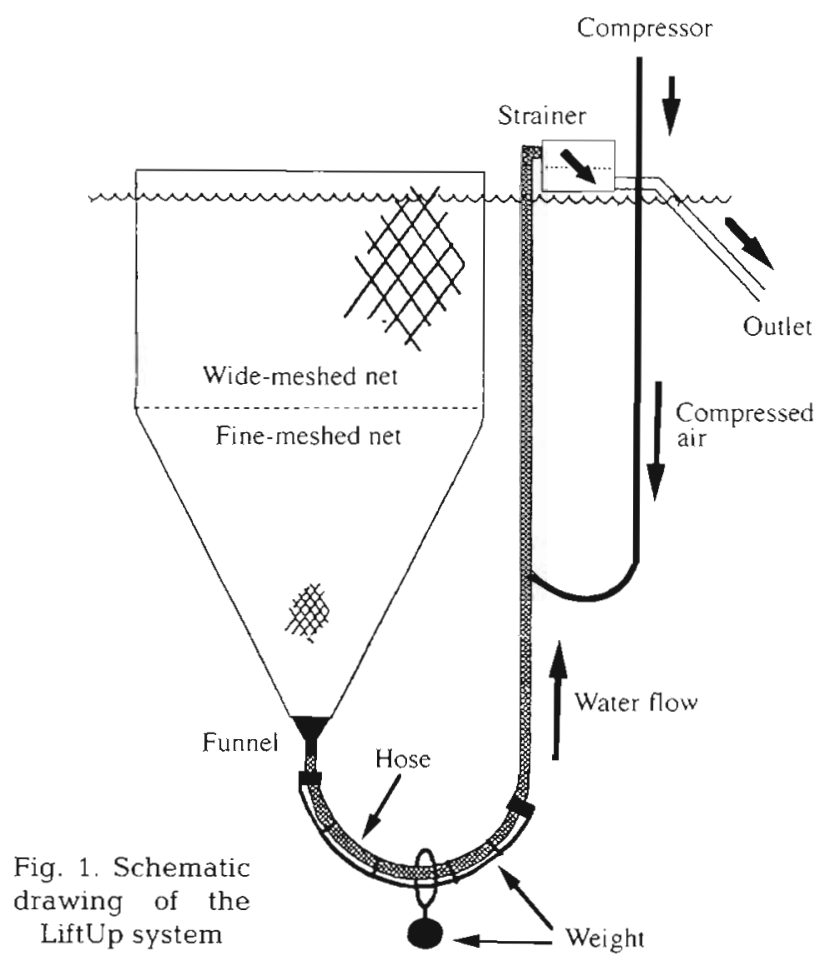

LiftUp. LiftUp is a netting cage consisting of a finemeshed funnel-shaped lower part and a wide-meshed upper part. A schematic drawing of the system is shown in Fig. 1. Dead fish, excess pellets and large faecal particles are trapped by the lower fine-meshed net and led to the bottom of the net where a hose is connected. By introducing a stream of compressed air into the bottom of the hose, the solid material is forced upward to the surface and separated by the strainer. LiftUp is very efficient, collecting nearly $100 \%$ of the waste food particles sized $6 \mathrm{~mm}$ or larger and nearly $70 \%$ of $4 \mathrm{~mm}$ particles (Birkeland \& Johnsen 1991).

Feed defector. A feed detector developed for automatic feeding control in sea-cage rearing of salmon was used (Juell et al. 1993). The feed detector is an acoustic transmitter and receiver mounted inside the rearing cage in a small net-cage and connected to an automatic feeder. When the echo energy from sinking feed pellets passing the detector has reached a preset level, the automatic feeder is temporarily switched off. A schematic drawing of the system is shown in Fig. 2.

Sampling. Samples were collected $2 \mathrm{~d}$ prior to treatment (Sampling 1), after $5 \mathrm{~d}$ of treatment (Sampling 2) and the first day following termination of medication

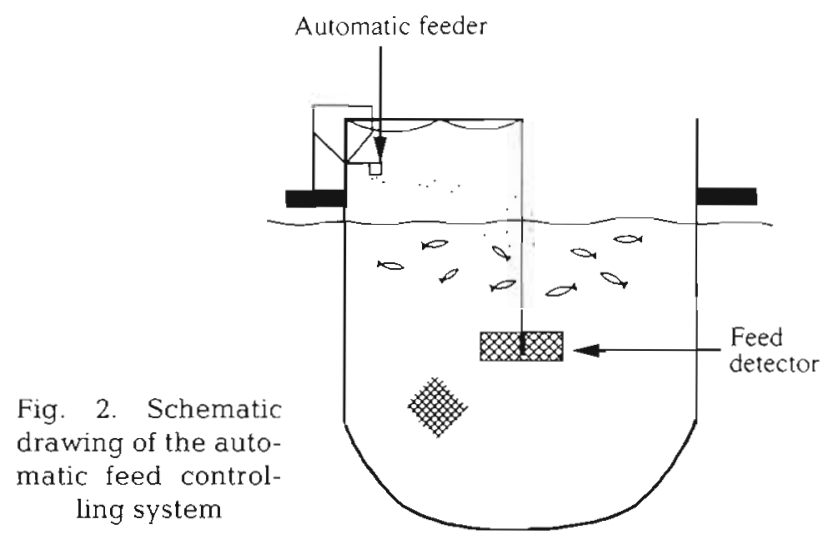

(Sampling 3). The fish were caught by gili-nets piaced within $30 \mathrm{~m}$ of the farm or by angling from the farm site. Samples of fish muscle were taken at the farm site and kept on ice during transport to the laboratory. The samples were stored at $-20^{\circ} \mathrm{C}$ until analysed.

Analysis. Muscle samples were prepared for highperformance liquid chromatography (HPLC) analysis following the procedure of Samuelsen et al. (1992). To quantify the residue of OXA in muscle, FLU was used as an internal standard and vice versa. To analyse the muscle samples the HPLC equipment and chromatographic assay described by Samuelsen (1990) were used. Samples with a muscle concentration exceeding $0.01 \mathrm{\mu g} \mathrm{g}^{-1}$ were considered positive.

\section{RESULTS AND DISCUSSION}

The results from Farms 1,2 and 3 are shown in Tables $1,2 \& 3$ respectively. Prior to medication at Farm 1 we found that $17 \%$ of the catch contained residues of FLU (Table 1). This was probably due to fish migrating from another fish farm in the area that had recently been medicated with this drug. That fish migrate between fish farms has previously been shown (Bjordal \& Skaar 1992, Bjordal \& Johnstone 1993). On

Table 1. Muscle residues of flumequine (FLU) in wild fish caught in the vicinity of Farm 1 prior to, during and after medication

\begin{tabular}{|c|c|c|c|c|c|}
\hline $\begin{array}{l}\text { Time of } \\
\text { sampling }\end{array}$ & Species & $\begin{array}{c}\text { No. of } \\
\text { individuals }\end{array}$ & $\begin{array}{c}\% \\
\text { Positive }\end{array}$ & $\begin{array}{l}\text { Mean muscle } \\
\text { conc. }\left(\mu g g^{-1}\right)\end{array}$ & $\begin{array}{l}\text { Max. muscle } \\
\text { conc. }\left(\mu g^{-1}\right)\end{array}$ \\
\hline $\begin{array}{l}\text { Prior to } \\
\text { medication }\end{array}$ & Saithe ${ }^{a}$ & 30 & 17 & 0.01 & 0.03 \\
\hline $\begin{array}{l}\text { During } \\
\text { medication }\end{array}$ & Saithe & 26 & 87 & 0.92 & 6.86 \\
\hline $\begin{array}{l}\text { After } \\
\text { medication }\end{array}$ & Saithe & 30 & 53 & 0.19 & 1.83 \\
\hline \multicolumn{6}{|c|}{ 'Pollachius virens } \\
\hline
\end{tabular}


the fifth day of medication, $87 \%$ of the catch contained FLU residues with a mean and maximum concentration of 0.92 and $6.86 \mu \mathrm{g} \mathrm{g}^{-1}$ respectively. The unexpectedly high percentage of the catch that contained FLU residues and the high concentrations found are best explained by an incorrect adjustment of the automatic feeder, since no other farm in the area was medicating with FLU at the time. During the first $5 \mathrm{~d}$ of treatment, pellets were occasionally thrown out of the cage and were therefore easily available to the wild fish. On the fifth day the automatic feeder was adjusted. By the end of medication the number of positive samples had decreased to $53 \%$ with a mean and maximum concentration of 0.19 and $1.83 \mathrm{\mu g} \mathrm{g}^{-1}$, respectively. These results show how easily drugs are spread to wild fish and how effective HPLC analysis is in revealing this. The large decrease in both mean and maximum concentrations occurring between samplings 2 and 3 can be best explained by excretion of the drug (Rogstad et al. 1993). The results indicate that, when the feed detector is connected to a correctly adjusted automatic feeder, the system effectively minimises the spread of medicated feed to the surroundings.

Apart from 1 sample containing $1.2 \mu \mathrm{g} \mathrm{g}^{-1}$, Table 2 shows that low residues of OXA were found in one-third of the catch at Farm 2 prior to medication. After $5 \mathrm{~d}$ of medication $42 \%$ of the catch contained OXA residues in muscle and in the majority of these samples the concentration was still low. On the day medication was terminated $83 \%$ of the catch contained OXA residues, with a mean and maximum concentration of 0.53 and $4.42 \mu \mathrm{g} \mathrm{g}^{-1}$, respectively. Every sampling at Farm 2 included some individuals which were atypical in that they contained much higher concentrations of OXA than
Table 2. Muscle residues of oxolinic acid (OXA) in wild fish caught in the vicinity of Farm 2 prior to, during and after medication

\begin{tabular}{|c|c|c|c|c|c|}
\hline $\begin{array}{l}\text { Time of } \\
\text { sampling }\end{array}$ & Species & $\begin{array}{l}\text { No. of } \\
\text { ndividuals }\end{array}$ & $\begin{array}{c}\% \\
\text { Positive }\end{array}$ & $\begin{array}{l}\text { Mean muscle } \\
\text { conc. }\left(\mu g^{-1}\right)\end{array}$ & $\begin{array}{l}\text { Max muscle } \\
\text { conc }\left(\mu g g^{-1}\right)\end{array}$ \\
\hline \multirow{5}{*}{$\begin{array}{l}\text { Prior to } \\
\text { medication }\end{array}$} & Saithe & 19 & 42 & 0.09 & 1.21 \\
\hline & $\operatorname{Cod}^{b}$ & 3 & 0 & 0 & 0 \\
\hline & Common dab & $b^{c} \quad 3$ & 33 & 0.01 & 0.01 \\
\hline & Lemon sole $^{d}$ & 4 & 0 & 0 & 0 \\
\hline & TOTAL & 29 & 32 & 0.09 & 1.21 \\
\hline \multirow{6}{*}{$\begin{array}{l}\text { During } \\
\text { medication }\end{array}$} & Saithe & 15 & 53 & 0.09 & 0.75 \\
\hline & Pollack ${ }^{e}$ & 10 & 0 & 0 & 0 \\
\hline & Cod & 3 & 33 & 0.01 & 0.01 \\
\hline & Salmon ${ }^{\prime}$ & 3 & 0 & 0 & 0 \\
\hline & Common dab & 2 & 50 & 0.03 & 0.06 \\
\hline & TOTAL & 33 & 42 & 0.06 & 0.75 \\
\hline \multirow{4}{*}{$\begin{array}{l}\text { After } \\
\text { medication }\end{array}$} & Saithe & 13 & 85 & 0.65 & 4.42 \\
\hline & Cod & 4 & 75 & 0.21 & 0.57 \\
\hline & Mackerel $^{g}$ & 1 & 100 & 0.25 & 0.25 \\
\hline & TOTAL & 18 & 83 & 0.53 & 4.42 \\
\hline
\end{tabular}

Table 3. Muscle residues of oxolinic acid (OXA) in wild fish caught in the vicinity of Farm 3 prior to, during and after medication

\begin{tabular}{|c|c|c|c|c|c|}
\hline $\begin{array}{l}\text { Time of } \\
\text { sampling }\end{array}$ & Species & $\begin{array}{l}\text { No. of } \\
\text { dividuals }\end{array}$ & $\begin{array}{c}\% \\
\text { Positive }\end{array}$ & $\begin{array}{l}\text { Mean muscle } \\
\text { conc. }\left(\mu \mathrm{g} \mathrm{g}^{-1}\right)\end{array}$ & $\begin{array}{l}\text { Max. muscle } \\
\text { conc. }\left(\mu g g^{-1}\right)\end{array}$ \\
\hline \multirow{9}{*}{$\begin{array}{l}\text { Prior to } \\
\text { medication }\end{array}$} & Saithe ${ }^{a}$ & 6 & 0 & 0 & 0 \\
\hline & $\operatorname{Cod}^{b}$ & 3 & 0 & 0 & 0 \\
\hline & Common dab ${ }^{c}$ & c 2 & 0 & 0 & 0 \\
\hline & Lemon sole ${ }^{d}$ & 1 & 0 & 0 & 0 \\
\hline & Haddock ${ }^{e}$ & 6 & 0 & 0 & 0 \\
\hline & Rainbow trout ${ }^{f}$ & $t^{f} \quad 9$ & 0 & 0 & 0 \\
\hline & Whiting $^{g}$ & 1 & 0 & 0 & 0 \\
\hline & Salmon ${ }^{\mathrm{h}}$ & 1 & 0 & 0 & 0 \\
\hline & TOTAL & 29 & 0 & 0 & 0 \\
\hline \multirow{4}{*}{$\begin{array}{l}\text { During } \\
\text { medication }\end{array}$} & Saithe & 4 & 50 & 0.21 & 0.51 \\
\hline & Whiting & 4 & 0 & 0 & 0 \\
\hline & Rainbow trout & 5 & 40 & 0.12 & 0.59 \\
\hline & TOTAL & 13 & 31 & 0.11 & 0.59 \\
\hline \multirow{5}{*}{$\begin{array}{l}\text { After } \\
\text { medication }\end{array}$} & Saithe & 22 & 28 & 0.02 & 0.15 \\
\hline & Mackerel $^{1}$ & 11 & 64 & 0.05 & 0.16 \\
\hline & Salmon & 1 & 0 & 0 & 0 \\
\hline & Rainbow trout & t 7 & 14 & 0.01 & 0.01 \\
\hline & TOTAL & 41 & 34 & 0.02 & 0.16 \\
\hline \multicolumn{6}{|c|}{$\begin{array}{l}\text { a Pollachius virens, }{ }^{\mathrm{b}} \text { Gadus morhua, }{ }^{\mathrm{c}} \text { Limanda limanda, }{ }^{\mathrm{d}} \text { Microstomus kitt, } \\
{ }^{\mathrm{e}} \text { Melanogrammus aeglefinus, }{ }^{\mathrm{f}} \text { Oncorhynchus mykiss, }{ }^{\mathrm{g}} \text { Merlangius merlangus, } \\
{ }^{\mathrm{h}} \text { Salmo salar, }{ }^{\mathrm{i}} \text { Scomber scombrus }\end{array}$} \\
\hline
\end{tabular}


the others. A possible explanation for both the atypical samples and the high percentage of positive samples found at Farm 2 is migration of wild fish from another fish farm in the area that also medicated with OXA at the same time.

At Farm 3, no drug residues were found in the wild fish population prior to medication (Table 3). During medication $31 \%$ of the samples contained OXA with mean and maximum concentrations of 0.11 and $0.59 \mu \mathrm{g}$ $\mathrm{g}^{-1}$, respectively. After medication was terminated $34 \%$ of the catch contained OXA, with a mean concentration of $0.02 \mu \mathrm{g} \mathrm{g}^{-1}$ and a maximum concentration of $0.16 \mu \mathrm{g} \mathrm{g}^{-1}$. Farm 3 is located in an area with few other fish farms, and the probability of drug-contaminated wild fish migrating from other fish farms is therefore lower than for Farms 1 and 2.

Ervik et al. (1994) suggest that the calculated mean muscle concentration in the wild fish caught in the vicinity of fish farms after medication is terminated depends on the amount of drug used during treatment. In the investigation of Ervik et al. (1994), Farms 5 and 6 used a total of $1.4 \mathrm{~kg}$ OXA and $6 \mathrm{~kg} \mathrm{FLU}$, respectively, which is comparable to the amount of drugs used in Farms 1, 2 and 3 in this investigation. On the day medication was terminated at Farms 5 and 6, 77\% of the catch contained drug residues at these farms. This is considerably higher than what was found at Farms 1 and 3 in this investigation. The maximum muscle concentration was 6.62 OXA $\mu \mathrm{g} \mathrm{g}^{-1}$ at Farm 5 and 15.74 FLU $\mu \mathrm{g} \mathrm{g}^{-1}$ at Farm 6, and the mean values were calculated to be 1.02 and $0.95 \mu \mathrm{g} \mathrm{g}^{-1}$, respectively. In approximately $30 \%$ of the samples from Farm 5 and $20 \%$ of the samples from Farm 6, the muscle concentration of the drugs exceeded $1 \mathrm{\mu g} \mathrm{g}^{-1}$, the corresponding values being $6,5.5$ and $0 \%$, respectively, for Farms 1, 2 and 3 . Therefore we conclude that the primary source causing the high concentrations of drugs in the wild fish is the medicated feed. The use of LiftUp or a feed detector during medication minimises this source. The equipment will not, however, prevent transfer of drugs to the wild fish via faeces and small drug-containing feed particles. Whether the low concentrations of drugs in wild fish are due to direct contact with faecal and small feed particles, to eating drug contaminated prey or to a combination of both is impossible to determine without further research.

In conclusion, the use of LiftUp or a feed detector reduces the amount of drugs found in wild fish caught in the vicinity of fish farms during and after medication. Combined with a temporary cessation of fishing in the vicinity of fish farms during and after medication, the use of such equipment will reduce the possibility of drug-containing fish being consumed. Another advan- tage of using this equipment is a reduced release of medicated pellets to the sediment which is often present under the cages in fish farms.

Acknowledgements. The technical assistance of Mrs Eli Tepstad, Mr Audun Høylandsskjær and Mrs Laila Unneland is greatly appreciated. This work was funded by The Norwegian Research Council for Fisheries Science and The Norwegian Department of Fisheries.

\section{LITERATURE CITED}

Birkeland, K., Johnsen, G. H. (1991). Vurdering av LiftUp fôroppsamlers effekt på utslipp av antibakterielle midler fra fiskeoppdrett. SFT-prosjekt 112/91. Rådgivende biologer AS, Bergen

Bjordal, A., Johnstone, A. D. F. (1993). Local movement of saithe (Pollachius virens L.) in the vicinity of fish farm cages. ICES mar. Sci. Symp. 196: 143-146

Bjordal, Å., Skaar, A. B. (1992). Tagging of saithe (Pollachius virens L.j at a Norwegian fish farm: preliminary results on migration. C.M.-ICES/G:35

Björklund, H., Bondestam, J., Bylund, G. (1990). Residues of oxytetracycline in wild fish and sediments from fish farms. Aquaculture 86: 359-367

Björklund, H., Råbergh, C. M. I., Bylund, G. (1991). Residues of oxolinic acid and oxytetracycline in fish and sediments from fish farms. Aquaculture 97: 85-96

Cravedi, J.-P., Choubert, G., Delous, G. (1987). Digestibility of chloramfenicol, oxolinic acid and oxytetracycline in rainbow trout and influence of these antibiotics on lipid digestibility. Aquaculture 60: 133-141

Ervik, A., Thorsen, B., Eriksen, V., Lunestad, B. T., Samuelsen, O. B. (1994). Impact of administering antibacterial agents on wild fish and blue mussels Mytilus edulis in the vicinity of fish farms. Dis. aquat. Org. 18: 45-51

Gröndel, J. L., Nouws, J. F. M., deJong, M., Schutte, A. R., Driessens, F. (1987). Pharmacokinetics and tissue distribution of oxytetracycline in carp (Cyprinus carpio L.) following different routes of administration. J. Fish Dis. 10: 153-163

Hustvedt, S. O., Salte, R., Kvendseth, O., Vassvik, V. (1991) Bioavailability of oxolinic acid in Atlantic salmon (Salmo salar L.) from medicated feed. Aquaculture 97: 305-310

Juell, J. E., Furevik, D. M., Bjordal, $\AA$. (1993). Demand feeding in salmon farming by hydroacoustic food detection. Aquacult. Eng. 12: 155-167

Møster, G. (1986). Bruk av antibiotika i fiskeoppdrett. Sogn og Fjordane Distriktshøgskule, Sogndal

Rogstad, A., Ellingsen, O. F., Syvertsen, C. (1993). Pharmacokinetics and bioavailability of flumequine and oxolinic acid after various routes of administration to Atlantic salmon in seawater. Aquaculture 110: 207-220.

Samuelsen, O. B. (1990). Simple and rapid determination of flumequine and oxolinic acid in salmon (Salmo salar) plasma by high-performance liquid chromatography and fluorescence detection. J. Chromatogr. 530: 452-457

Samuelsen, O. B., Lunestad, B. T., Husevåg, B., Hølleland, T. Ervik, A. (1992). Residues of oxolinic acid in wild fauna following medication in fish farms. Dis. aquat. Org. 12 $111-119$ 